\title{
Jagged1/Notch3 Signaling Modulates Hemangioma-Derived Pericyte Proliferation and Maturation
}

\author{
Yi Jia Siyuan Chen ${ }^{b}$ Bo Xiang ${ }^{a}$ Yuan Li Li Lic $^{\mathrm{a}}$ Qi Wang

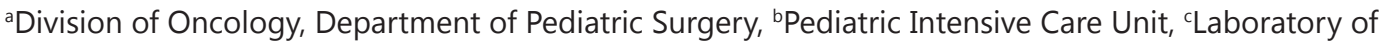 \\ Pathology, West China Hospital of Sichuan University, Chengdu, China
}

\section{Key Words}

Infantile hemangiomas $\bullet$ Pericyte $\bullet$ Notch $•$ Proliferation $\bullet$ Maturation

\begin{abstract}
Background: The Notch signaling pathway has been implicated in the pericyte phenotype, but its exact roles in hemangioma-derived pericytes (Hem-pericytes) remain ill defined. Methods: Hem-pericytes were stimulated by immobilized recombinant Jagged1. The potential mechanisms of Notch-induced Hem-pericytes growth arrest were investigated by cell cycle assay, and the role of the Notch in promoting Hem-pericyte maturation was also analyzed by real-time PCR and western blot. Results: Activation of Notch3 in Hem-pericytes significantly reduced cell proliferation and inhibited cell cycle transition. This event was associated with an

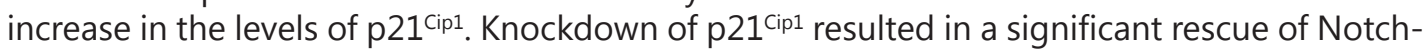
induced cell growth arrest and an entry into the cell cycle. We showed that Jagged 1 activation of Notch3 signaling upregulated the expression of the pericyte contractile markers smooth muscle myosin heavy chain (smMHC) and $\alpha$-smooth muscle actin ( $\alpha \mathrm{SMA})$, concomitant with an increase in the expression of myocardin in Hem-pericytes. We further revealed that the endothelial-derived Jagged1 modulated the Hem-pericyte phenotype via a contactdependent mechanism. Conclusions: Our results demonstrated that Jagged1 activation of Notch3 resulted in a significant decrease in cell proliferation while concomitantly promoting Hem-pericyte maturation. These data provide initial evidence that Notch induces a quiescent phenotype in Hem-pericytes.
\end{abstract}

\section{Introduction}

Infantile hemangiomas (IHs) are the most common vascular tumor of childhood, affecting $5 \%$ to $10 \%$ of all infants. If left untreated, these tumors are characterized by a rapid growth phase during the first year of life, followed by slow involution, which may continue until the age of 7-10 years [1]. In 10\% of cases, IHs grow dramatically and destroy tissue, impair function or even threaten life [2, 3].

$Y$. Ji and S. Chen contributed equally to this work.

Yi Ji, M.D., Ph.D.,

and Siyuan Chen, M.D., Ph.D.,
Division of Oncology, Department of Pediatric Surgery; and Pediatric Intensive Care Unit, West China Hospital of Sichuan University, 37\# Guo-Xue-Xiang, Chengdu, 610041 (China); Tel. +86 13980544622, E-Mail jijiyuanyuan@163.com / siy_chen@163.com

\section{KARGER}




\section{Cellular Physiology Cell Physiol Biochem 2016;40:895-907 \begin{tabular}{l|l|l} 
and Biochemistry 10.1159/000453148 & $\begin{array}{l}\text { (C) 2016 The Author(s). Published by S. Karger AG, Basel } \\
\text { www.karger.com/cpb }\end{array}$ \\
\hline Published online: December 07, 2016
\end{tabular} \\ Ji et al.: Jagged1/Notch3 Signaling in Hemangioma-Derived Pericytes}

In proliferating IHs, one of the most important characteristics of vascular remodeling is the abundance of endothelial cells (ECs) and pericytes, both of which form nascent vessels with irregular lumens that are associated with high blood flow [4, 5]. In contrast, involuting IHs have less cellular density but are characterized by prominent well-formed vascular channels or lumens, combined with a severe reduction of blood flow [6, 7]. The appearance of well-organized luminal structures imply that IHs become 'more mature' at the involuting phase [8].

Pericytes are derived from the mesenchyme and present within the basement membrane of blood vessels. In contrast to vSMCs, pericytes are directly embedded within the endothelial basement membrane. Quiescent pericytes/vSMCs are fully differentiated, non-proliferative cells that express high levels of a subset of genes required for their contractile functions [9]. Interestingly, recent data have offered evidence that proliferating hemangioma-derived pericytes (Hem-pericytes) are distinct from involuting Hem-pericytes at both the transcriptional and functional levels [10]. These contrasting studies revealed that proliferating Hem-pericytes exhibit altered angiogenic cytokines and acquire altered phenotypes to adapt to the abnormal physical environment of the tumor by undergoing a form of reprogramming that involves an increase in proliferation and a decrease in contractility $[10,11]$. However, the molecular mechanisms of IH involution that are associated with Hempericyte maturation from the proliferating phase to the involuting phase have not been completely elucidated.

The Notch pathway is a conserved ligand-receptor signaling pathway that plays a prominent role in cell fate, including proliferation, differentiation, and maturation [12]. It has been suggested that Notch signaling is silent during the early stages of angiogenesis (when active vascular cell proliferation is required) but activated during vessel maturation (when vascular cells cease proliferation and likely undergo maturation-associated cell cycle arrest) $[9,13]$. These data support the hypothesis that Notch signaling helps control vessel homeostasis by maintaining vascular cell quiescence.

Current data suggest that several Notch components are involved in the pathogenesis of IH [14-17]. Remarkably, recent studies have revealed that endothelial-derived Jagged1 can induce hemangioma-derived stem cells (HemSCs) to acquire a pericyte-like phenotype, which is a crucial step in the vasculogenesis of IH. Disruption of the juxtacrine interaction between endothelial Jagged1 and Notch receptors on HemSCs inhibits blood vessel formation in IH murine models [18].

Herein, we report on a series of studies that were performed to determine whether Notch signaling could influence the Hem-pericyte phenotype. Our findings demonstrate that Jagged1 activation of Notch3 signaling blocks cell proliferation and induces the expression of vascular smooth muscle contractile markers in Hem-pericytes. Our data describe a novel pro-quiescence function for Jagged1/Notch3 signaling in Hem-pericytes.

\section{Materials and Methods}

\section{Cell extraction and isolation}

This study was approved by the Ethics Committee of the West China Hospital of Sichuan University. Written informed consent was obtained from the patient's parents for all tissues obtained for the study, according to the Declaration of Helsinki. The characteristics of the patients are list in Table 1.The clinical diagnosis of IHs was confirmed in the Department of Pathology. Single-cell suspensions were prepared from IH specimens [19, 20], and Hem-pericyte isolation was performed as previously described [21]. Briefly, hemangioma tissue was transferred on ice immediately after resection, and was quickly minced into 1-2 $\mathrm{mm}^{3}$ specimens. Rinsed the pieces of tissues with PBS+1\% GPS $(292 \mu \mathrm{g} / \mathrm{ml}$ Glutamine, $100 \mathrm{U} / \mathrm{ml}$ penicillin, $100 \mu \mathrm{g} / \mathrm{ml}$ streptomycin) once to remove the surface blood. The specimens were digested with $0.2 \%$ collagenase A (Sigma, St. Louis, MO) in DMEM supplemented with 2\% FBS and 1\% GPS. After the digestion was completed, the tissue homogenate was filtered through a 100- $\mu$ m cell strainer (BD, CA, USA). Red blood cells were lysed by incubating the sample in ammonium chloride (Sigma). Next, cells were filtered through 


\section{Cellular Physiology Cell Physiol Biochem 2016;40:895-907

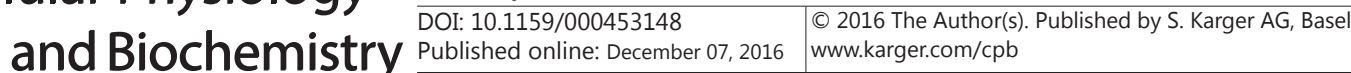 \\ Ji et al.: Jagged1/Notch3 Signaling in Hemangioma-Derived Pericytes}

Table 1. Characteristics of the proliferating and involuting IH subjects. * m, month; F, female; M, male; IH, infantile hemangioma; Hem-pericyte, hemangioma-derived pericyte

\begin{tabular}{|c|c|c|c|c|c|c|}
\hline Phase of IH & $\begin{array}{l}\text { Patient } \\
\text { number }\end{array}$ & Gender & $\begin{array}{l}\text { Age at time of } \\
\text { operation }(\mathrm{m})\end{array}$ & Location & Size $(\mathrm{cm})$ & $\begin{array}{l}\text { Hem-pericyte } \\
\text { number }\end{array}$ \\
\hline Proliferating & 1 & $\mathrm{~F}$ & 2 & Inner thigh & $3.0 \times 2.0$ & Hem-pericyte- 1 \\
\hline \multirow[t]{5}{*}{$\mathrm{IH}$} & 2 & $\mathrm{~F}$ & 4 & Scalp & $2.5 \times 2.5$ & Hem-pericyte-2 \\
\hline & 5 & M & 2 & Neck & $2.5 \times 2.0$ & \\
\hline & 6 & M & 4 & Right forearm & $2.0 \times 1.2$ & \\
\hline & 7 & $\mathrm{~F}$ & 3 & Lower back & $3.5 \times 1.3$ & \\
\hline & 8 & $\mathrm{~F}$ & 2 & Right forearm & $2.5 \times 2.0$ & \\
\hline \multirow[t]{7}{*}{ Involuting $\mathrm{IH}$} & 3 & $\mathrm{~F}$ & 12 & Lower back & $3.5 \times 3.0$ & Hem-pericyte-3 \\
\hline & 4 & $\mathrm{~F}$ & 10 & Upper & $2.0 \times 2.0$ & Hem-pericyte- 4 \\
\hline & & & & abdominal wall & & \\
\hline & 9 & $\mathrm{~F}$ & 15 & Lower back & $1.5 \times 1.5$ & \\
\hline & 10 & M & 12 & Scalp & $2.5 \times 2.0$ & \\
\hline & 11 & M & 13 & Scalp & $2.5 \times 2.5$ & \\
\hline & 12 & $\mathrm{~F}$ & 10 & Lower back & $3.0 \times 2.0$ & \\
\hline
\end{tabular}

Table 2. Primer sequences

a 40- $\mu \mathrm{m}$ strainer to get a single-cell suspension, and incubated with FITC-conjugated mouse anti-human PDGFR $\beta$ (BD Bioscience, San Jose, CA). The Hem-pericytes were purified by using a flow cytometer (BD Bioscience) to separate the PDGFR $\beta^{+}$cells. The purity of the Hem-pericytes was $>95 \%$, as determined by the positive SMA and SmM$\mathrm{HC}$ expression and the negative expression of CD31 (endothelial cells). Human retinal pericytes (RPCs) were obtained from Lonza (Allendale, NJ, USA). Primary HUVECs were obtained from the Chinese Academy of Sciences (Shanghai, China).

The coculture experiment was performed as previously described [21, 22].

RNA extraction and quantitative real-time PCR analysis

The mRNA of the target genes expressed in IH tissues and Hem-pericytes was isolated using Trizol reagent (Invitrogen, Carlsbad, CA, USA) and reverse transcribed into cDNA. Quantitation of the relative mRNA abundance was performed using an ABI Prism 7700 Sequence Detection System (Applied Biosystems). The primers are listed in Table 2.

\section{Immunofluorescence and double staining}

The IH specimens were de-paraffinized, and avidin and biotin were added with the blocking agents. The blocking agent was blotted off, and the first antibody was added to incubate overnight at $4^{\circ} \mathrm{C}$. The slides were washed and incubated with the second antibody at room temperature for 30 minutes. Images were acquired using a Leica microscope camera (Leica Microsystems, Wetezlar, Germany).

Western blot analysis

The protein samples were separated by sodium dodecyl sulfate-polyacrylamide gel electrophoresis (SDS-PAGE) and electrophoretically transferred onto a nitrocellulose membrane. The protein bands were visualized using enhanced ECL-associated fluorography. 


\section{Cellular Physiology Cell Physiol Biochem 2016;40:895-907

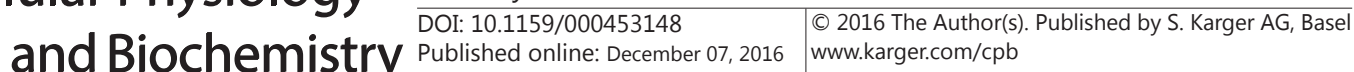 \\ Ji et al.: Jagged1/Notch3 Signaling in Hemangioma-Derived Pericytes}

Activation of Notch receptor

Immobilization of Jagged1 Fc or control Fc was performed as described [23]. Briefly, PBS containing $20 \mu \mathrm{g} / \mathrm{ml} \mathrm{Fc}$-specific human IgG (Sigma) was added to the wells and incubated for $2 \mathrm{~h}$ at room temperature. The solution was then aspirated, and PBS containing $10 \mu \mathrm{g} / \mathrm{ml}$ of either recombinant rat Jagged1 fused to human Fc (R\&D Systems) or human Fc control protein (Sigma) was added to each well, and the samples were incubated at $4^{\circ} \mathrm{C}$ overnight. The solution was aspirated before the cells were plated.

Small interfering RNA methods

Notch3 small interfering RNA (siRNA), p21 $1^{\mathrm{Cip} 1}$ siRNA and scrambled control sequences were prepared by Ambion and were transferred into Hem-pericyte using the Amaxa nucleofector.

\section{Plasmid transfection}

Plasmid transfection was performed as previously described [24]. Briefly, HUVECs were seeded into plates $24 \mathrm{~h}$ prior to plasmid transfection. Cells were then transfected with the empty vector or human cDNA ORF clone of Jagged1 (Origene, Rockville, MD) using MegaTran 1.0 (Origene) for $6 \mathrm{~h}$ in OptiMEM I Reduced Serum Medium (Invitrogen). After $6 \mathrm{~h}$, the transfection media was removed and the cells washed. The cells were replenished with growth media (EBM-2).

\section{Cell proliferation analysis}

Changes in cellularity of the Hem-pericyte were determined by electronic cell counting (Coulter Counter). In addition, the BrdU cell proliferation assay was performed according to the manufacturer's instructions [19].

Cell cycle analysis

The fraction of the cell population in each phase of the cell cycle was determined as a function of the DNA content using flow cytometry analysis (Beckman Coulter, Brea, CA, USA).

\section{Statistical analyses}

All data are expressed as the mean \pm SD for all paired statistical comparisons. An analysis of variance (ANOVA) followed by Tukey's test was performed, and a $P$ value less than 0.05 was considered significant.

\section{Results}

Notch3, Hes1 and HEYL were highly expressed in involuting Hem-pericytes

Previous studies have demonstrated that the IH life-cycle is associated with clear spatialtemporal changes in the expression of Notch members $[14,15]$. We analyzed the expression levels of Jagged1, Notch3, Hes1 and HEYL in proliferating and involuting IHs using real-time PCR (Fig. 1A and 1B). Consistent with previous studies [15], our data showed that the gene expression of Jagged1 in involuting IHs was significantly higher than that in proliferating IHs. We also observed upregulation of Hes1 and HEYL mRNA within involuting IHs compared with proliferating IHs (Fig. 1C).

Jagged 1 has been detected predominantly present in hemangioma ECs, whereas Notch3, Hes1 and HEYL are primarily expressed in hemangioma pericytes [15, 17]. We examined the expression of Notch genes in Hem-pericytes in vitro (Fig. 1D). The Hem-pericyte lines that we used are derived from two proliferating and two involuting IHs. We designated these cells P-Hem-pericyte (proliferating) and I-Hem-pericyte (involuting). Real-time PCR showed that the I-Hem-pericytes exhibited higher gene expression levels of Notch3, Hes1 and HEYL than did P-Hem-pericytes and RPCs (Fig. 1E).

\section{Jagged1 activates Notch3 signaling in involuting Hem-pericytes}

We next determined the effect of Jagged1 on Notch target gene mRNA levels in I-Hempericytes. Quantitative real-time PCR revealed a significant increase in Notch target gene mRNA levels (specifically, Hes1 and HEYL). In contrast, DAPT, a $\gamma$-secretase inhibitor that 


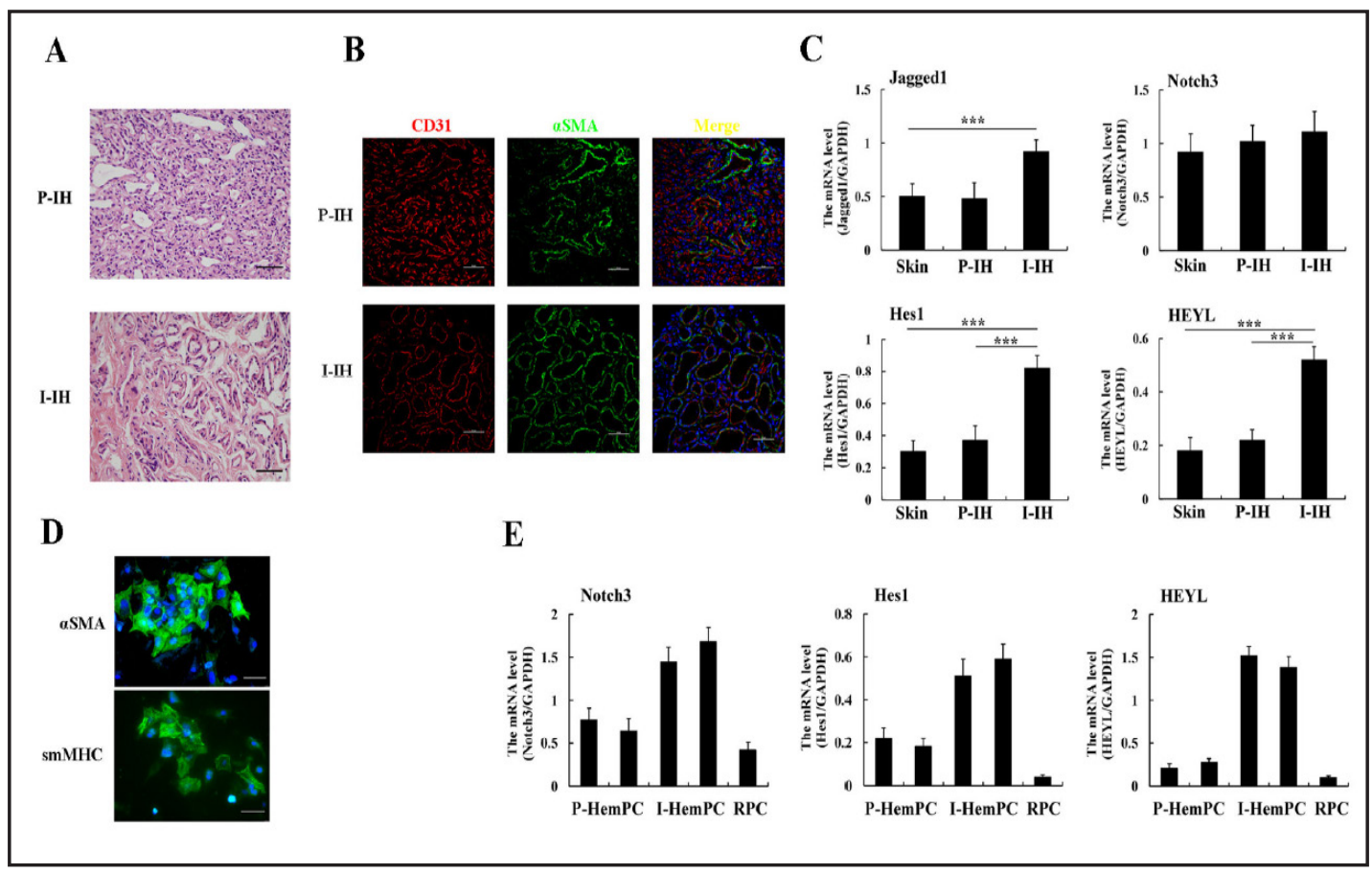

Fig 1. Expression of Notch components in IHs and Hem-pericytes. (A), Hematoxylin and eosin (H\&E)stained sections of two different phases of IH. ( $n=6$; Scale bar, $100 \mu \mathrm{m})$. (B), Two different phases of IH tumor sections stained for the endothelial marker, CD31 (red), the smooth muscle marker, $\alpha$ SMA (green), and nuclei (blue) ( $\mathrm{n}=6$; Scale bar, $50 \mu \mathrm{m})$. (C), Real-time PCR expression assays measure the Jagged1, Notch3, Hes1 and HEYL in proliferating and involuting IHs. Graphed are the mean \pm SD. The data are presented as the relative abundance of each target gene normalized to GAPDH levels. ( $\mathrm{n}=6$; ${ }^{* * *} P<0.001$ ) (ANOVA). (D), Hem-pericytes stained for $\alpha$ SMA and smMHC. (E), Gene transcript levels of Notch3, Hes1 and HEYL in proliferating and involuting Hem-pericytes. The results are shown as the mean $\pm \operatorname{SD}(n=6)$.

inhibits Notch receptor cleavage and thus NICD production, significantly attenuated Jagged1induced Hes1 and HEYL gene expression (Fig. 2A). To further corroborate these findings, we targeted Notch3 by siRNA-mediated knockdown and compared the results to those of a scrambled siRNA control. Using real-time PCR and western blot analyses, we demonstrated successful knockdown of Notch3 expression in Hem-pericytes (Fig. 2B). Knockdown of the Notch3 receptor significantly reduced the levels of Hes1 and HEYL transcripts that were induced by Jagged1 stimulation (Fig. 2C).

\section{Jagged1/Notch3 signaling inhibits involuting Hem-pericyte proliferation}

Because of the observation that I-Hem-pericytes showed a significantly lower proliferation rate than P-Hem-pericytes both in vivo and in vitro [10], we postulated that Notch signaling might be involved in Hem-pericyte proliferation. To test this hypothesis, we investigated whether increased activation of Notch signaling affected I-Hem-pericyte proliferation. Stimulation of Hem-pericyte with Jagged1 revealed a growth rate that was significantly slower than that of control at the pre-confluence, confluence and postconfluence stages, as indicated by the total cell numbers at different time points (Fig. 3A). These data were confirmed by BrdU incorporation at the pre-confluence stage (Fig. 3B).

We next examined whether Jagged1-induced cell growth arrest is dependent on the activation of the Notch3 pathway or on the proteolytic cleavage of signal-transducing NICD by $\gamma$-secretase. As shown in Fig. 3C, Jagged1-induced cell proliferation arrest was significantly rescued by knockdown of Notch3. Furthermore, similar results were obtained by treatment of Hem-pericytes with DAPT (Fig. 3D).

\section{KARGER}



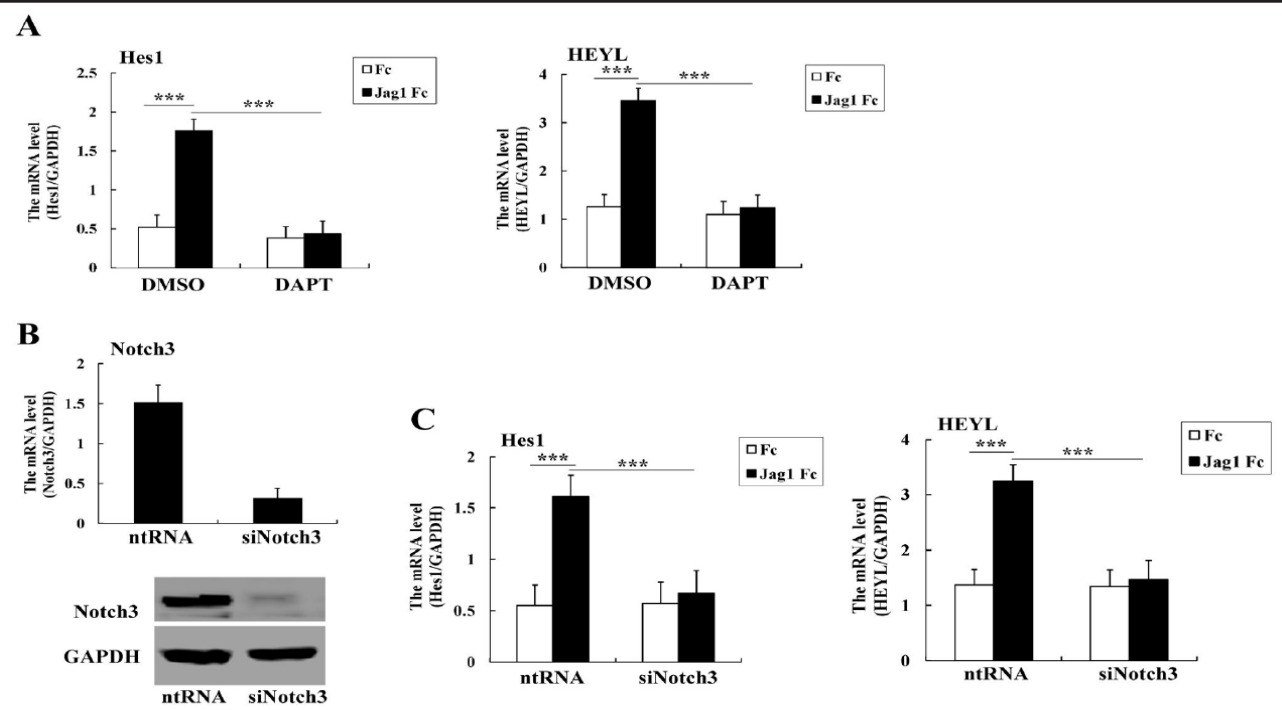

Fig 2. Jagged1 activates Notch3 and induced Hes1 and HEYL expression in Hem-pericytes. (A), Hem-pericytes were incubated with Fc or Jagged1 Fc for $24 \mathrm{~h}$ before treating the cells with DMSO (0.1\%) or DAPT $(10 \mu \mathrm{M})$ for another $24 \mathrm{~h}$. Hes1 and HEYL gene expression was then determined by real-time PCR $(\mathrm{n}=6$; ${ }^{* * *} P<0.001$ ) (ANOVA). (B), Hem-pericytes were transfected with 200 pmol of nontargeting RNA (ntRNA) or siNotch3. Real-time PCR and immunoblotting showing the expression knockdown effect of Notch3 siRNA on Notch3 in Hem-pericytes ( $\mathrm{n}=4)$. (C), Jagged1-induced Hes1 and HEYL gene expression was significantly reduced by siNotch3. Hem-pericytes were exposed to Fc or Jagged1 Fc for $48 \mathrm{~h}$, and Hes1 and HEYL gene expression was analyzed by real-time PCR. The results are shown as the mean \pm SD and were analyzed by ANOVA $\left(\mathrm{n}=6\right.$; $\left.{ }^{* * *} P<0.001\right)$ (ANOVA).

Fig 3. Activated Notch3 signaling attenuates Hem-pericyte proliferation. (A), Growth curve analysis in Hem-pericytes. Hem-pericytes were incubated with $\mathrm{Fc}$ or Jagged $1 \mathrm{Fc}$ at $3.0 \times 10^{4}$ cells/well in 24-well plates in complete growth medium. The cells were electronically counted at different time points in culture $(\mathrm{n}=6$; $* *$ $P<0.01$, *** $P<0.001$ ) ( $t$-test). (B), Analysis
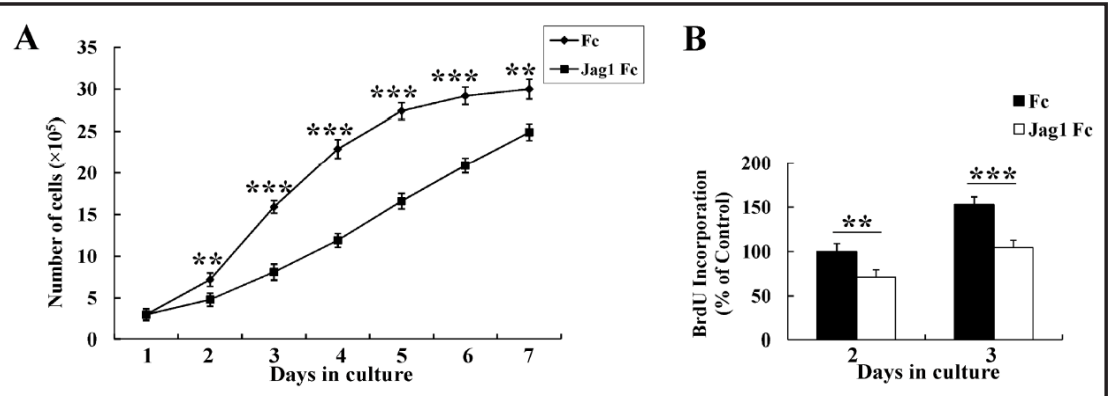

of cell proliferation in

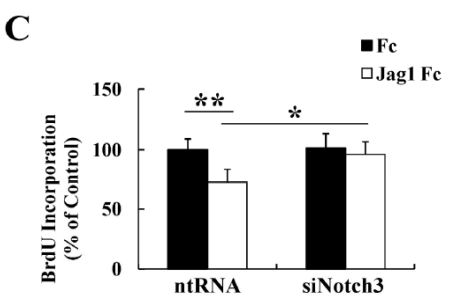

D

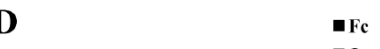

Hem-pericytes. Hem-pericytes were incubated with Fc or Jagged1 Fc in 96-well pates in complete growth medium up to $48 \mathrm{~h}$ or $72 \mathrm{~h}$ preconfluence. Cell proliferation was analyzed by BrdU incorporation $(\mathrm{n}=6$; ** $P<0.01,{ }^{* * *} P<0.001$ ) ( $t$-test). (C), Hem-pericytes with selective Notch3 knockdown were placed on FC or Jagged1 Fc for $30 \mathrm{~h}$, then pulsed with BrdU for $18 \mathrm{~h}$. A BrdU cell proliferation assay was performed as outlined in the Methods section ( $n=6$; $^{*} P<0.05$, $\left.{ }^{* *} P<0.01\right)$ ( $t$-test). (D) Hem-pericytes were incubated with Fc or Jagged1 Fc for $30 \mathrm{~h}$ in the presence of DMSO $(0.1 \%)$ or DAPT $(10 \mu \mathrm{M})$, then pulsed with fresh culture medium containing BrdU (1:2000) for $18 \mathrm{~h}$. The cells were processed for the BrdU proliferation assay. $(\mathrm{n}=$ 6; ** $\left.P<0.01,{ }^{* * *} P<0.001\right)$ ( $t$-test).

\section{KARGER}


Fig 4. Jagged $1 /$ Notch3 suppresses Hem-pericyte S-phase entry by modulation of p21 ${ }^{\text {cip1 }}$. (A), Fluorescence-activated cell sorting (FACS) analysis of cell cycle with accompanying cell cycle phase proportions in Hem-pericytes. The data shown were collected from 10,000 events. Jagged1 Fc induced a shift in cell cycle toward $G_{0} / G_{1}$ phase and reduced the proportion of cells in S phase $(n=6)$. (B), Hem-pericytes were plated on Fc or Jagged1 Fc for $48 \mathrm{~h}$, and the cell lysates were collected for immunoblotting to detect $\mathrm{p} 21^{\mathrm{Cip} 1}, \mathrm{p} 27^{\mathrm{Kip} 1}$, cyclin D1, CKD2, CDK4, CKD6 and phospho- $\mathrm{Rb}(\mathrm{n}=4)$. (C), Hem-pericytes were transfected with ntRNA or siRNA

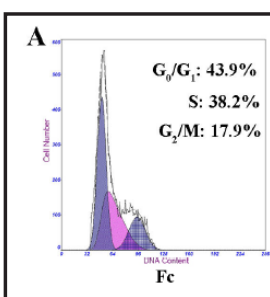

B

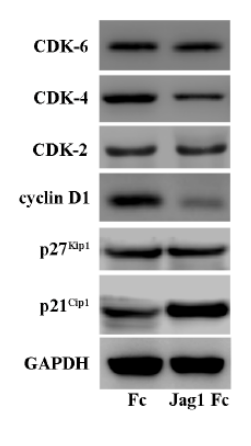

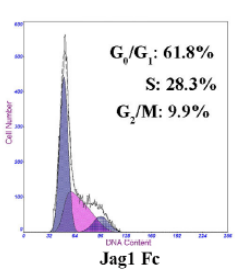

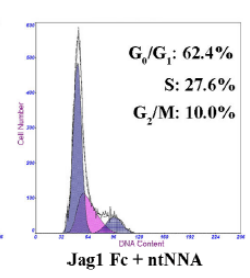

D

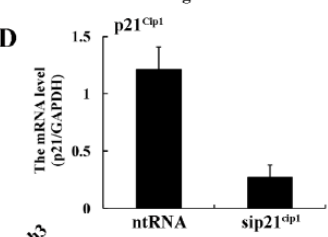

C
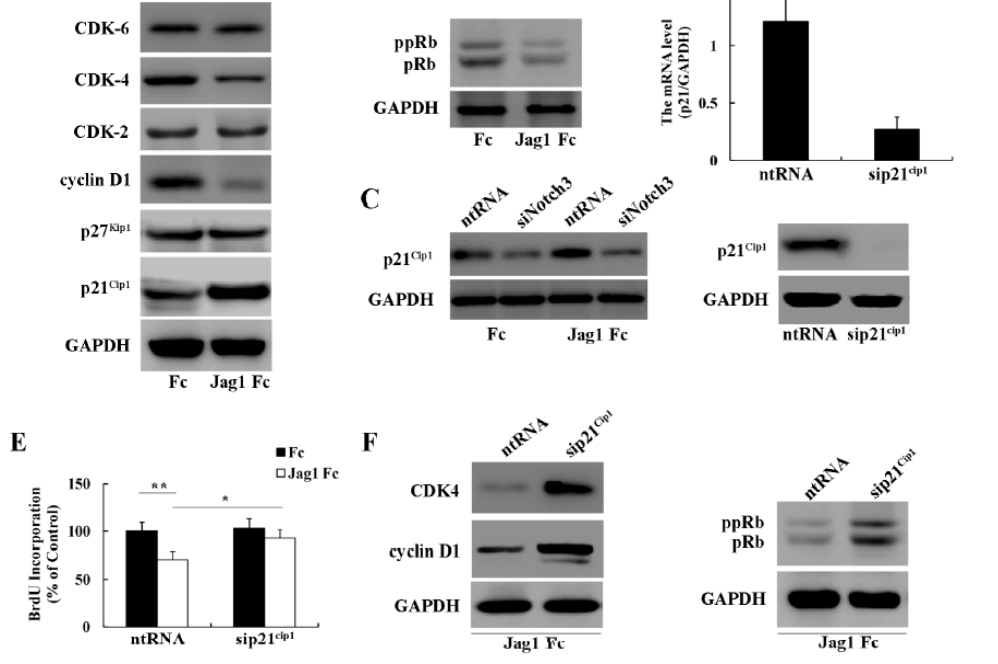

targeting Notch3 and placed on Fc or Jagged1 Fc for $48 \mathrm{~h}$. The cells were processed for immunoblotting to detect $\mathrm{p} 21^{\mathrm{Cip} 1}(\mathrm{n}=4)$. (D), Hem-pericytes were transfected with small-interfering targeting $\mathrm{p} 21^{\mathrm{Cip} 1}$, and efficiency was analyzed by real-time PCR and western blot $(n=4)$. $(E)$, Hem-pericytes were transfected with ntRNA or siRNA targeting p21 $1^{\mathrm{Cip} 1}$ and placed on Fc or Jagged1 Fc for $30 \mathrm{~h}$, then pulsed with BrdU for $18 \mathrm{~h}$. A BrdU cell proliferation assay was performed as outlined in the Methods section. ( $\mathrm{n}=6$; $^{*} P<0.05,{ }^{* *} P<0.01$ ) (ANOVA). (F), Control and p21 $1^{\mathrm{Cip} 1}$ knockdown Hem-pericytes were placed on Fc or Jagged1 Fc for $48 \mathrm{~h}$, and cell lysates were immunoblotted to detected cyclin D1, CDK4 and phospho- $\mathrm{Rb}(\mathrm{n}=4)$.

Table 3. Effect of Jagged1/Notch3 on the cell cycle distribution of Hem-pericytes (mean \pm $\mathrm{SD}, \mathrm{n}=6$ ). $* P<0.05$ compared with the Fc treated control, ${ }^{\dagger} P<0.05$ compared with the Jagged1 Fc group (ANOVA)

\begin{tabular}{llll}
\hline Group & $\mathrm{G}_{0} / \mathrm{G}_{1}$ & $\mathrm{~S}$ & $\mathrm{G}_{2} / \mathrm{M}$ \\
\hline $\mathrm{Fc}$ & $44.7 \pm 3.3$ & $37.5 \pm 3.2$ & $17.8 \pm 3.8$ \\
Jagged1 Fc & $62.6 \pm 3.6^{*}$ & $27.7 \pm 3.9$ & $9.7 \pm 2.1$ \\
Jagged1 Fc + ntRNA & $61.9 \pm 3.4^{*}$ & $28.0 \pm 2.6$ & $10.1 \pm 2.2$ \\
Jagged1 Fc + siNotch3 & $53.7 \pm 3.5^{\dagger}$ & $32.3 \pm 2.7$ & $14.0 \pm 1.9$ \\
\hline
\end{tabular}

Table 4. Effect of $\mathrm{p} 21^{\text {cip1 }}$ on cell cycle of Hem-pericytes (mean $\pm \mathrm{SD}, \mathrm{n}=6){ }^{*} P<0.05$ compared with the Jagged1 Fc + ntRNA group. (ANOVA)

\begin{tabular}{llll}
\hline Group & $\mathrm{G}_{0} / \mathrm{G}_{1}$ & $\mathrm{~S}$ & $\mathrm{G}_{2} / \mathrm{M}$ \\
\hline Jagged1 Fc & $62.0 \pm 3.9$ & $27.2 \pm 2.7$ & $10.8 \pm 2.8$ \\
+ ntRNA & & & \\
Jagged1 Fc & $55.7 \pm 3.4^{*}$ & $31.8 \pm 2.9$ & $12.5 \pm 2.3$ \\
+ sip21 Cip1 & & & \\
\hline
\end{tabular}

Jagged1/Notch3 signaling inhibits cell cycle progression in involuting Hem-pericytes via the $221^{\text {cip } 1}$ pathway.

Hem-pericytes were plated on Jagged1 Fc or Fc control for $48 \mathrm{~h}$, and the cell cycle distribution was analyzed using PI staining. As shown in Fig. 4A, Jagged1 Fc induced an approximately $18.0 \%$ increase in the $G_{0} / G_{1}$ population compared with the $F c$ control, whereas the $S$ phase and $G_{2} / M$ populations were reduced by approximately $10.0 \%$ and $8.0 \%$, 


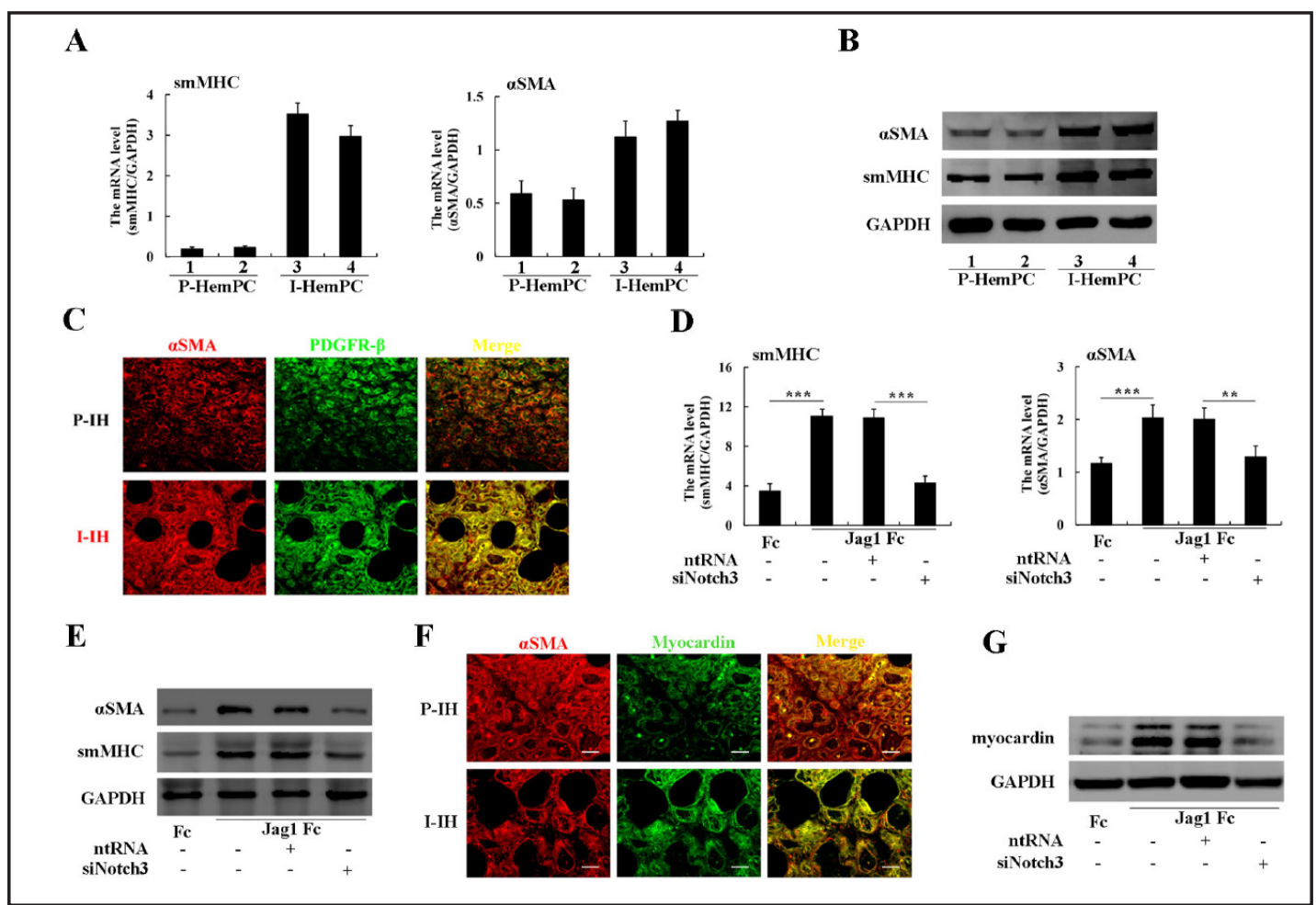

Fig 5. Jagged1/Notch3 upregulated the expression of endogenous pericyte markers. (A), Real-time PCR analysis of smMHC and $\alpha$ SMA gene expression in Hem-pericytes from proliferating and involuting IHs. The results are shown as the mean \pm SD of duplicated assays from one of three identical experiments $(n=6)$. (B), Western blot analysis of smMHC and $\alpha$ SMA proteins expression in Hem-pericytes from proliferating and involuting IHs $(n=4)$. (C), Proliferating and involuting IH tumor sections stained for the pericyte markers, $\alpha$ SMA (red) and PDGFR $\beta$ (green). (D), Involuting Hem-pericytes with selective Notch3 knockdown were placed on Fc or Jagged1 Fc for $48 \mathrm{~h}$, and smMHC and $\alpha$ SMA gene expression was analyzed by real-time PCR ( $\mathrm{n}=6$; ${ }^{* *} P<0.01,{ }^{* * *} P<0.001$ ) (ANOVA). (E), Involuting Hem-pericytes with selective Notch3 knockdown were placed on Fc or Jagged $1 \mathrm{Fc}$ for $48 \mathrm{~h}$, and smMHC and $\alpha$ SMA protein expression was analyzed by western blot $(n=4) .(F)$, Immunofluorescence was performed for co-staining myocardin with $\alpha$ SMA. The yellow in the merged images indicates the overlapping area. $(\mathrm{n}=6$; Scale bar, $100 \mu \mathrm{m})$. (G), Control and Notch3-knockdown Hem-pericytes were placed on Fc or Jagged1 Fc for $48 \mathrm{~h}$, and cell lysates were immunoblotted to detect myocardin $(n=4)$.

respectively. In contrast, knockdown of Notch3 abolished the Jagged1-induced cell cycle arrest and resulted in a greater number of Hem-pericytes in the S phase (Table 3).

It is recognized that Notch3 modulates the vascular cell cycle via regulating the expression of $\mathrm{CDK}$ inhibitors, including $\mathrm{p} 21^{\mathrm{Cip} 1}$ and $\mathrm{p} 27^{\mathrm{Kip} 1}$ [25]. Surprisingly, Jagged1 Fc activation enhanced p21 ${ }^{\text {Cip } 1}$ expression in Hem-pericytes, whereas changes in the expression of $\mathrm{p} 27^{\mathrm{Kip} 1}$ were not detected (Fig. 4B). Furthermore, Jagged 1 activation not only decreased the expression of cyclin D1 and its associated kinase, CDK-4, but also reduced the phosphorylation of $\mathrm{Rb}$ compared with the $\mathrm{Fc}$ control group. No change in the expression of CDK2 and CDK6 was observed following Jagged1 activation. We found that Jagged1 upregulated the expression of $\mathrm{p} 21^{\mathrm{Cip} 1}$ in the non-targeted RNA control Hem-pericytes but not in cells with reduced Notch3 expression (Fig. 4C).

Next, we used an siRNA targeting p21 $1^{\text {Cip1 }}$ to suppress induction by Jagged1 signaling (Fig. 4D). We found a significant reduction of BrdU incorporation in ntRNA-transfected cells plated on Jagged1 Fc at $48 \mathrm{~h}$ compared with the Fc control, whereas knockdown of p21 ${ }^{\text {Cip } 1}$ rescued the Jagged1-induced suppression of Hem-pericyte proliferation (Fig. 4E). These results were confirmed using PI staining in conjunction with cell cycle analysis (Table 4). Furthermore, 


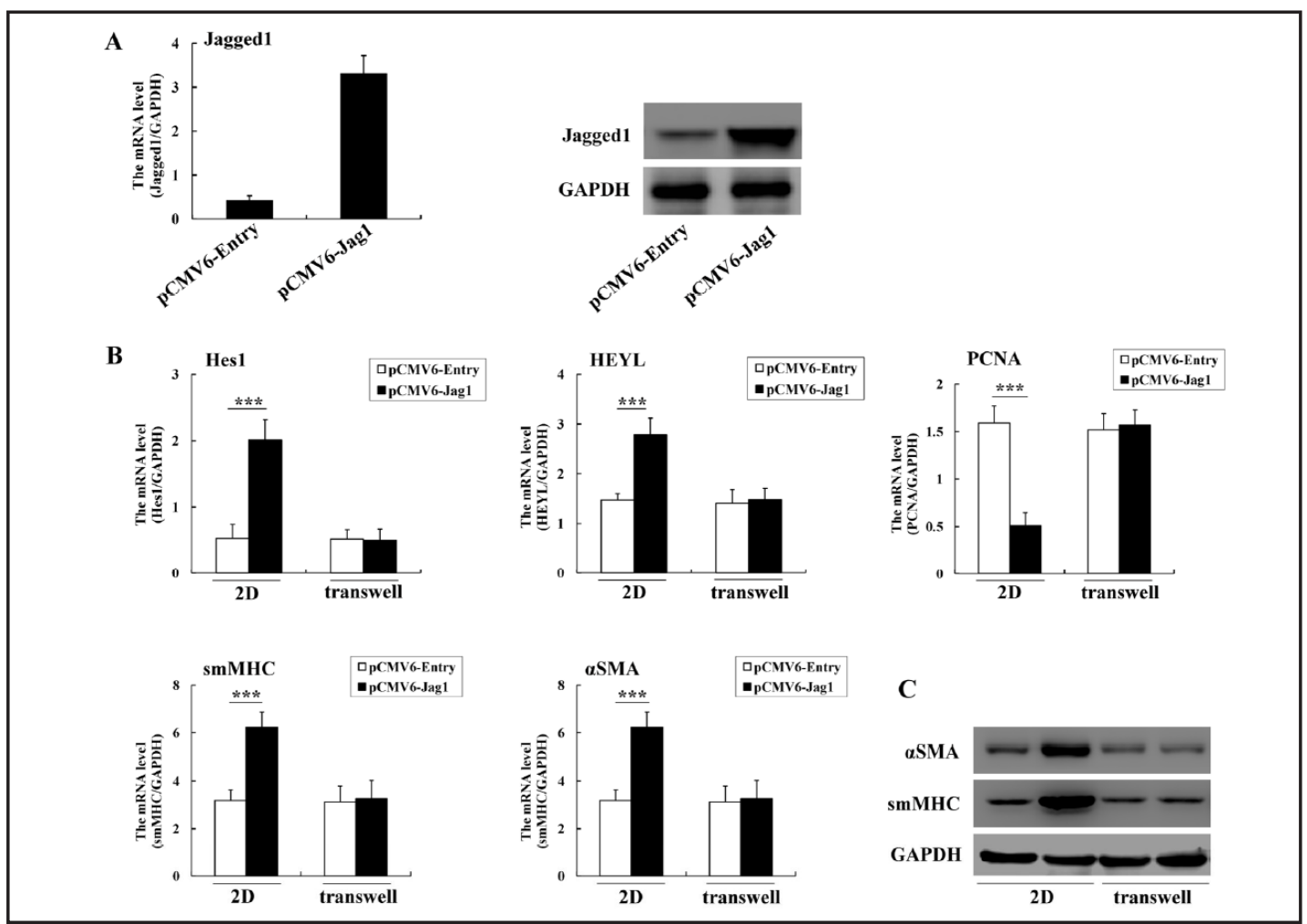

Fig 6. A coculture system reveals the functional significance of crosstalk between Hem-pericytes and ECs. (A), HUVECs were transfected with the empty vector (pCMV6-Entry) or Jagged1 expression vector (pCMV6-Jagged1), real-time PCR and immunoblotting showing increased Jagged1 level in HUVECs containing the pCMV6-Jagged1 expression plasmid ( $\mathrm{n}=4$ ). (B), Real-time PCR analysis of Hes1, HEYL, PCNA, smMHC and $\alpha$ SMA expression in Hem-pericytes cultured together with pCMV6-Entry HUVECs or pCMV6-Jagged1 HUVECs for $72 \mathrm{~h}$, either as 2D cultures allowing for physical contact between Hem-pericytes and HUVECs or in transwell cultures where the two cell types were separated by a membrane $\left(n=6\right.$; $\left.{ }^{* *} P<0.001\right)$ (ANOVA). (C), Western blot analysis of smMHC and $\alpha$ SMA in cell lysates from Hem-pericytes cultured together with pCMV6-Entry HUVECs or pCMV6-Jagged1 HUVECs for $72 \mathrm{~h}$. Western blot for GAPDH was used as a loading control $(n=4)$.

the reduced cyclin D1 and CDK-4 expression as well as the decreased phosphorylation of Rb by Jagged 1 activation was rescued by a lack of p21 $1^{\text {Cip } 1}$ (Fig. 4F).

\section{Jagged1/Notch3 promotes involuting Hem-pericyte maturation}

Compared with proliferating Hem-pericytes, involuting Hem-pericytes expressed higher levels of contractile markers for mature pericytes, including smMHC and $\alpha$ SMA (Fig. 5A, 5B and 5C). In Jagged1 Fc-stimulated cells, the expression of genes associated with the maturation/contractile phenotype, including smMHC and $\alpha \mathrm{SMA}$, were increased in compared with the Fc control cells (Fig. 5D). We further confirmed that Jagged 1 induced these pericyte/ SMC markers at the protein level (Fig. 5E). However, under identical experimental conditions, knockdown of Notch3 abolished the Jagged1-induced smMHC and $\alpha$ SMA expression (Fig. 5D and 5E).

Pericytes and vSMCs belong to the same lineage and category [13]. We examined the expression of myocardin in IH tissues. Immunofluorescence studies showed that myocardin was expressed in perivascular regions and that it colocalized with $\alpha$ SMA (Fig. 5F). To investigate whether myocardin is involved in the Hem-pericyte fate, we examined myocardin levels in Hem-pericytes after Jagged1 activation. As shown in Fig. 5G, Jagged1 upregulated myocardin protein expression in Hem-pericytes. We further studied the requirement for 


\section{Cellular Physiology Cell Physiol Biochem 2016;40:895-907

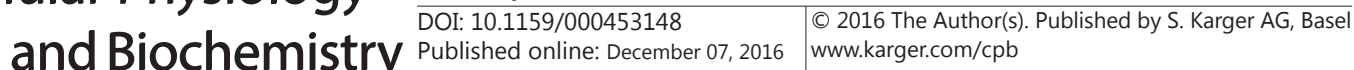 \\ Ji et al.: Jagged1/Notch3 Signaling in Hemangioma-Derived Pericytes}

Notch3 for myocardin expression induced by Jagged1. Western blotting for myocardin revealed that Notch3 knockdown resulted in reduced myocardin expression in response to Jagged1.

Endothelial-derived Jagged1 modulates involuting Hem-pericyte phenotype via a cell contact-dependent mechanism

As mentioned previously, Jagged1 is primarily expressed in IH ECs [15]. We transfected HUVECs with an expression plasmid for Jagged1 (Fig. 6A) and cocultured them with Hempericytes. After $72 \mathrm{~h}$, Hem-pericytes and HUVECs were separated by fluorescence-activated cell sorting (FACS) based on CD31 expression in the HUVECs. We confirmed that endothelialderived Jagged1 is biologically active because it induced the expression of Hes1 and HEYL in Hem-pericytes. Of particular important, EC-derived Jagged1 obviously repressed PCNA expression and induced smMHC and $\alpha$ SMA expression in Hem-pericytes (Fig. 6B and 6C). Using a transwell coculture system, we assessed the need for physical contact for the ECdependent regulation of genes in Hem-pericytes. Separation of Hem-pericytes and HUVECs by a membrane permeable to proteins, but not cells, rendered HUVECs unable to induce Hes1 and HEYL expression in Hem-pericytes (Fig. 6B). Furthermore, we observed no changes in PCNA, smMHC or $\alpha$ SMA expression in Hem-pericytes after transwell coculture with HUVECs (Fig. 6B and 6C).

\section{Discussion}

Interestingly, studies investigating the function of Notch signaling in pericyte/vSMC have yielded conflicting results, describing both anti-proliferation and pro-proliferation functions as well as both anti-maturation and pro-maturation functions for Notch [26, 27]. These discrepancies have been speculated to be a result of the highly context-dependent nature and tight spatio-temporal regulation of Notch pathway components during vascular development [9]. In the present study, Jagged1 stimulation resulted in activation of Notch3 in Hem-pericytes concomitant with growth arrest, contractile marker expression and pericyte maturation. In contrast, inhibition of Notch3 signaling using both pharmacological and molecular interventions reversed these effects of Jagged1. These findings provided substantial new evidence that Jagged1/Notch3 signaling activation may be required for the establishments of a mature, quiescent Hem-pericyte phenotype. Our observations raise the intriguing possibility that in the involuting phase, upregulated Notch signaling in Hempericytes could have an pro-quiescent effect on hemangiomagenesis and, therefore, on hemangioma regression.

The $\mathrm{p} 21^{\mathrm{Cip} 1}$ and $\mathrm{p} 27^{\mathrm{Kip} 1}$ proteins inactivate the cyclin-CDK complexes in $\mathrm{G}_{1}$ leading to cell cycle arrest, and therefore, they function in pericyte/cSMC growth regulation. Notch signaling has significant effect on $\mathrm{p} 21^{\mathrm{Cip} 1}$ and $\mathrm{p} 27^{\mathrm{kip} 1}$ activity and cell cycle progression, thus having implications for growth dysregulation in vascular disease and cell transformation [28]. Our studies showed an increased expression of $\mathrm{p} 21^{\mathrm{Cip} 1}$ upon Jagged1 stimulation and a decreased expression of $\mathrm{p} 21^{\text {Cip } 1}$ by knockdown of Notch3 in Hem-pericyte, implying that p $21^{\text {Cip1 }}$ has a role in Hem-pericyte proliferation. Furthermore, we provided direct evidence indicating that one mechanism through which Jagged1/Notch3 interferes with the cell cycle machinery in Hem-pericytes is the upregulation of p21 ${ }^{\text {Cip1 }}$, which impairs the capacity of Hem-pericytes to enter S phase. Interestingly, we did observe the induction of p27 $7^{\text {kip } 1}$ following Notch stimulation of Hem-pericytes, further supporting the idea of cell-specific activation of Notch effector molecules [29].

There is compelling evidence that most pericyte/SMC markers are controlled by serum response factor (SRF), which binds to a sequence known as a CArG box and recruits a potent coactivator, myocardin, for pericyte/SMC differentiation and maturation [9, 13]. Mouse embryos deficient in myocardin show no evidence of $\mathrm{VSMC}$, indicating that myocardin is a necessary and sufficient factor for vSMC development in vivo [30]. Depending on the cell 


\section{Cellular Physiology Cell Physiol Biochem 2016;40:895-907 \begin{tabular}{l|l|l|l|l|l}
\hline DOI: 10.1159/000453148 & $\begin{array}{l}\text { () 2016 The Author(s). Published by S. Karger AG, Basel } \\
\text { www.karger.com/cpb }\end{array}$ \\
\hline and Biochemistry
\end{tabular} \\ Ji et al.: Jagged1/Notch3 Signaling in Hemangioma-Derived Pericytes}

type and context, the Notch pathway can generate either an inhibitory or promotional effect on myocardin expression, thus mediating vSMC differentiation and maturation [31, 32]. Furthermore, Notch and myocardin can synergistically induce vSMC differentiation and maturation [33]. In the present study, we were intrigued by these distinguishing features and demonstrated that activation of Jagged1/Notch3 signaling was sufficient to promote a contractile phenotypic maturation that was characterized by increased smMHC and $\alpha \mathrm{SMA}$ expression. Importantly, the expression level of smMHC, the most reliable marker for pericyte/vSMC, was upregulated by Notch, strongly suggesting that Notch induces Hempericyte maturation, not merely several pericyte markers. These observations, together with the findings that Notch upregulated myocardin expression in Hem-pericytes, highlight a potential mechanism whereby the activation of Jagged1/Notch3, via regulation of the myocardin pathway, promotes Hem-pericyte maturation.

The differentiation of mature Hem-pericyte from their progenitors, HemSCs, may involve a series of steps. Previously, Boscolo et al. [18] showed that endothelial-derived Jagged-1 was sufficient to stimulate HemSCs to differentiate toward a pericyte-like phenotype, suggesting that Notch plays a positive role in the vasculogenic process, with angiogenic sprouting as secondary event. However, in a different study, very few HemSCs were detected in the involuting phase of IH [34]. In this regard, it is plausible that Notch signaling, including possible augmentation of other signaling pathways (e.g., myocardin), not only plays a fundamental role in the formation of blood vessels in early proliferating IH but is also required to promote maturation of the vasculature in involuting IH. Further investigation is needed to conclusively identify the specific function of Notch in different stages of vascular remodeling in IHs.

Solid evidence has emerged supporting a pivotal role for Notch receptor/ligands in mediating EC in pericyte communication and influencing the phenotypic state of pericyte or vice versa [35, 36]. We proceeded based on our previous supposition that the Notch pathway might also contribute to establishing two distinct subpopulations at different steps of angiogenesis in IHs, such as ECs versus pericytes [29, 37, 38]. We demonstrated that the Jagged1 level was increased in involuting IH tissues [15]. These observations, coupled with the findings from our coculture studies, highlight the potential role of endothelial-derived Jagged1 in transducing Hem-pericyte Notch receptor. Furthermore, we found that ECs need to be in apposition to pericytes to confer induction of Hes1 and HEYL. It may be that actual physical contact between Hem-pericytes and ECs is needed in the context of vascular remodeling [39].

\section{Conclusion}

In conclusion, we have demonstrated that Notch3 and its target genes are upregulated within involuting Hem-pericytes. Jagged1 activation of Notch3 reduces Hem-pericyte proliferation and maintains the cells in the $G_{0} / G_{1}$ phase, at least in part, by the stimulation of p21 ${ }^{\text {Cip1 }}$ production. Furthermore, Jagged1/Notch3 signaling constitutes an instructive signal for Hem-pericyte maturation, associated with an increase in the expression of myocardin. Our data provide a mechanism by which Jagged1/Notch3 signaling contributes to the quiescent and contractile phenotype of involuting Hem-pericyte.

\section{Acknowledgments}

This work was supported by grants from the National Natural Science Foundation of China (81401606, 81400862 and 31201095), and the Science Foundation for The Excellent Youth Scholars of Sichuan University (2015SU04A15).

\section{Disclosure Statement}

The authors declare that they have no completing interests. 


\section{Cellular Physiology Cell Physiol Biochem 2016;40:895-907

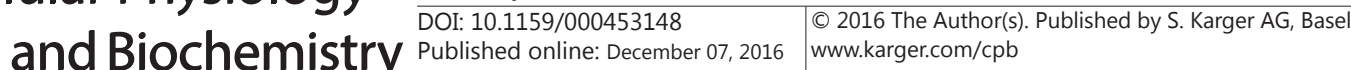 \\ Ji et al.: Jagged1/Notch3 Signaling in Hemangioma-Derived Pericytes}

\section{References}

1 Tollefson MM, Frieden IJ: Early growth of infantile hemangiomas: what parents' photographs tell us. Pediatrics 2012;130:e314-e320.

2 Ji Y, Chen S, Xiang B, Xu Z, Jiang X, Liu X, Wang Q, Lu G, Yang L: Clinical features and management of multifocal hepatic hemangiomas in children: a retrospective study. Sci Rep 2016; 6:31744.

3 Ji Y, Wang Q, Chen S, Xiang B, Xu Z, Li Y, Zhong L, Jiang X, Yang X: Oral atenolol therapy for proliferating infantile hemangioma: A prospective study. Medicine (Baltimore) 2016; 95:e3908.

4 Zheng N, Ding X, Sun A, Jahan R: PDK1 Activity Regulates Proliferation, Invasion and Growth of Hemangiomas. Cell PhysioL Biochem 2015; 36:1903-1910.

5 Jiang H, Wu X, Wang H, Huang C, Zhang L: Combined Anti-PLGF and Anti-Endostatin Treatments Inhibit Ocular Hemangiomas. Cell Physiol Biochem 2015; 36:930-936.

6 Janmohamed SR, Madern GC, de Laat PC, Oranje AP: Educational paper: Pathogenesis of infantile haemangioma, an update 2014 (part I). Eur J Pediatr 2015;174:97-103.

7 Greenberger S, Bischoff J: Pathogenesis of infantile haemangioma. Br J Dermatol 2013;169:12-19.

8 Khan ZA, Boscolo E, Picard A, Psutka S, Melero-Martin JM, Bartch TC, Mulliken JB, Bischoff J: Multipotential stem cells recapitulate human infantile hemangioma in immunodeficient mice. J Clin Invest 2008;118:2592-2599.

9 Boucher J, Gridley T, Liaw L: Molecular pathways of notch signaling in vascular smooth muscle cells. Front Physiol 2012;3:81.

10 Boscolo E, Mulliken JB, Bischoff J: Pericytes from infantile hemangioma display proangiogenic properties and dysregulated angiopoietin-1. Arterioscler Thromb Vasc Biol 2013;33:501-509.

11 Lee D, Boscolo E, Durham JT, Mulliken JB, Herman IM, Bischoff J: Propranolol targets the contractility of infantile haemangioma-derived pericytes. Br J Dermatol 2014;171:1129-1137.

12 Dufraine J, Funahashi Y, Kitajewski J: Notch signaling regulates tumor angiogenesis by diverse mechanisms. Oncogene 2008;27:5132-5137.

13 Morrow D, Guha S, Sweeney C, Birney Y, Walshe T, O'Brien C, Walls D, Redmond EM, Cahill PA: Notch and vascular smooth muscle cell phenotype. Circ Res 2008;103:1370-1382.

14 Calicchio ML, Collins T, Kozakewich HP: Identification of signaling systems in proliferating and involuting phase infantile hemangiomas by genome-wide transcriptional profiling. Am J Pathol 2009;174:1638-1649.

15 Wu JK, Adepoju O, De Silva D, Baribault K, Boscolo E, Bischoff J, Kitajewski J: A switch in Notch gene expression parallels stem cell to endothelial transition in infantile hemangioma. Angiogenesis 2010;13:1523.

$16 \mathrm{Wu}$ JK, Kitajewski JK: A potential role for notch signaling in the pathogenesis and regulation of hemangiomas. J Craniofac Surg 2009;20:698-702.

17 Adepoju 0, Wong A, Kitajewski A, Tong K, Boscolo E, Bischoff J, Kitajewski J, Wu JK: Expression of HES and HEY genes in infantile hemangiomas. Vasc Cell 2011;3:19.

18 Boscolo E, Stewart CL, Greenberger S, Wu JK, Durham JT, Herman IM, Mulliken JB, Kitajewski J, Bischoff J: JAGGED1 signaling regulates hemangioma stem cell-to-pericyte/vascular smooth muscle cell differentiation. Arterioscler Thromb Vasc Biol 2011;31:2181-2192.

19 Ji Y, Chen S, Li K, Xiao X, Zheng S, Xu T: The role of beta-adrenergic receptor signaling in the proliferation of hemangioma-derived endothelial cells. Cell Div 2013;8:1.

20 Ji Y, Li K, Xiao X, Zheng S, Xu T, Chen S: Effects of propranolol on the proliferation and apoptosis of hemangioma-derived endothelial cells. J Pediatr Surg 2012;47:2216-2223.

21 Bryan BA, D'Amore PA: Pericyte isolation and use in endothelial/pericyte coculture models. Methods Enzymol 2008;443:315-331.

22 Franco M, Roswall P, Cortez E, Hanahan D, Pietras K: Pericytes promote endothelial cell survival through induction of autocrine VEGF-A signaling and Bcl-w expression. Blood 2011;118:2906-2917.

23 Varnum-Finney B, Wu L, Yu M, Brashem-Stein C, Staats S, Flowers D, Griffin JD, Bernstein ID: Immobilization of Notch ligand, Delta-1, is required for induction of notch signaling. J Cell Sci 2000;113:4313-4318.

24 Ai Q, Ma X, Huang Q, Liu S, Shi T, Zhang C, Zhu M, Zhang Y, Wang B, Ni D et al: High-level expression of Notch1 increased the risk of metastasis in T1 stage clear cell renal cell carcinoma. Plos One 2012;7:e35022. 


\section{Cellular Physiology Cell Physiol Biochem 2016;40:895-907 \begin{tabular}{ll|l} 
DOI: 10.1159/000453148 & $\begin{array}{l}\text { O 2016 The Author(s). Published by S. Karger AG, Basel } \\
\text { www.karger.com/cpb }\end{array}$
\end{tabular} \\ Ji et al.: Jagged1/Notch3 Signaling in Hemangioma-Derived Pericytes}

25 Tanner FC, Boehm M, Akyurek LM, San H, Yang ZY, Tashiro J, Nabel GJ, Nabel EG: Differential effects of the cyclin-dependent kinase inhibitors p27(Kip1), p21(Cip1), and p16(Ink4) on vascular smooth muscle cell proliferation. Circulation 2000;101:2022-2025.

26 Bhattacharyya A, Lin S, Sandig M, Mequanint K: Regulation of vascular smooth muscle cell phenotype in three-dimensional coculture system by Jagged1-selective Notch3 signaling. Tissue Eng Part A 2014;20:1175-1187.

27 Li X, Zhang X, Leathers R, Makino A, Huang C, Parsa P, Macias J, Yuan JX, Jamieson SW, Thistlethwaite PA: Notch3 signaling promotes the development of pulmonary arterial hypertension. Nat Med 2009;15:12891297.

28 Boucher JM, Harrington A, Rostama B, Lindner V, Liaw L: A receptor-specific function for Notch2 in mediating vascular smooth muscle cell growth arrest through cyclin-dependent kinase inhibitor 1B. Circ Res 2013;113:975-985.

29 Ji Y, Chen S, Li K, Li L, Xu C, Xiang B: Signaling pathways in the development of infantile hemangioma. J Hematol Oncol 2014;7:13.

30 Li S, Wang DZ, Wang Z, Richardson JA, Olson EN: The serum response factor coactivator myocardin is required for vascular smooth muscle development. Proc Natl Acad Sci U S A 2003;100:9366-9370.

31 Doi H, Iso T, Yamazaki M, Akiyama H, Kanai H, Sato H, Kawai-Kowase K, Tanaka T, Maeno T, Okamoto E et al: HERP1 inhibits myocardin-induced vascular smooth muscle cell differentiation by interfering with SRF binding to CArG box. Arterioscler Thromb Vasc Biol 2005;25:2328-2334.

32 Proweller A, Pear WS, Parmacek MS: Notch signaling represses myocardin-induced smooth muscle cell differentiation. J Biol Chem 2005;280:8994-9004.

33 Doi H, Iso T, Sato H, Tanaka T, Arai M, Kurabayashi M: Notch Signaling Accelerates Vascular Smooth Muscle Differentiation by Inducing Myocardin Gene Expression and by Enhancing the Transactivating Function of Myocardin. Circulation 2006;114: 45.

34 Yu Y, Flint AF, Mulliken JB, Wu JK, Bischoff J: Endothelial progenitor cells in infantile hemangioma. Blood 2004;103:1373-1375.

35 Yang K, Proweller A: Vascular smooth muscle Notch signals regulate endothelial cell sensitivity to angiogenic stimulation. J Biol Chem 2011;286:13741-13753.

36 Scheppke L, Murphy EA, Zarpellon A, Hofmann JJ, Merkulova A, Shields DJ, Weis SM, Byzova TV, Ruggeri ZM, Iruela-Arispe ML et al: Notch promotes vascular maturation by inducing integrin-mediated smooth muscle cell adhesion to the endothelial basement membrane. Blood 2012;119:2149-2158.

37 Ji Y, Chen S, Xu C, Li L, Xiang B: The use of propranolol in the treatment of infantile haemangiomas: an update on potential mechanisms of action. Br J Dermatol 2015;172:24-32.

38 Ji Y, Chen S, Li K, Xiao X, Xu T, Zheng S: Upregulated autocrine vascular endothelial growth factor (VEGF)/ VEGF receptor-2 loop prevents apoptosis in haemangioma-derived endothelial cells. Br J Dermatol 2014;170:78-86.

39 Sainson RC, Harris AL: Regulation of angiogenesis by homotypic and heterotypic notch signalling in endothelial cells and pericytes: from basic research to potential therapies. Angiogenesis 2008;11:41-51. 